$$
B S N=428313
$$

PHYTOPATHOLOGICAL CONSEQUENCES OF CHANGING AGRICULTURAL METHODS

III. VEGETABLES, FLOWERS AND FRUIT UNDER GLASS

Fytopathologische gevolgen van veranderende landbouwmethoden

III. Groenten, bloemen en fruit onder glas
G. P. TERMOLeN

Proefstation voor de Groente- en Fruitteelt onder Glas, Naaldwijk, The Netherlands 
Neth. J. Pl. Path. 73 (1967): Supp. 1: 116-129

\title{
PHYTOPATHOLOGICAL CONSEQUENCES OF CHANGING AGRICULTURAL METHODS
}

\section{II. VEGETABLES, FLOWERS AND FRUIT UNDER GLASS}

\author{
Fytopathologische gevolgen van veranderende landbouwmethoden \\ III. Groenten, bloemen en fruit onder glas
}

\author{
G. P. Termohlen
}

Proefstation voor de Groente- en Fruitteelt onder Glas, Naaldwijk, The Netherlands

\section{INTRODUCTION}

The glasshouse industry is always searching for changes in methods of cultivation of any kind with the following objects: to spread production, to raise the production per unit area, to improve the quality of the product and to reduce the cost price. And, in doing so, the industry pays little heed to the phytopathological consequences. Such consequences can, as a matter of fact, hardly be predicted beforehand. However, practice has shown that improvements in disease control have followed this intensification closely and that its expenses are relatively low, so mostly justified. The question is, mainly, to find among the various control possibilities that method best adapted to the growing conditions and the cheapest. The requirements as to the quality of products are so high nowadays that it is almost unthinkable that they could be satisfied without taking any phytosanitary measures (BARNES, 1954; CHESTER, 1950).

Before starting my actual subject I think it would be desirable to say a few words on the development and the present situation of glasshouse culture, especially in Western Europe. I will give you some data about the climate, the area under glass and the production of a few crops to illustrate the present position of horticulture under glass.

\section{CLIMATE, AREA UNDER GLASS AND PRODUCTION}

The concentration of glass in North West Europe is not so strange, considering the climate: the summers are not too hot and the winters not too cold (Thran \& Broekhuizen, 1965). There are thus advantages in respect to the cooling and heating required. On the other hand there is the disadvantage of too short daylength during the winter season. This becomes particularly important as there is a tendency to want to grow many crops the whole year through. This has consequences affecting the development of growing methods for the unfavourable periods of the year and also consequences with regard to the control of plant diseases, as will appear later on.

The increase in the volume of demand in the ever more industrialising countries of Europe and - after the second worldwar - the demand for more luxury products you can buy all the year through, has stimulated extension of the area of glass. This growing demand applies particularly to quality produce, which the glasshouse industry can meet to a high degree.

There are no reliable statistical data on the world area under glass or under plastic. Roughly estimated, however, $70 \%$ of the total area under glass is in North West Europe, of which $55 \%$ is in the Netherlands. The main concentra- 
tions under glass are situated, in descending order in the Netherlands, England, Western Germany, Scandinavia, Belgium, Guernsey, Northern France and Ireland.

To give you an idea of the expansion of the area under glass, especially after the second world war, some figures for the Netherlands are given in Table 1.

TABLE 1. Area of glass in ha'.

Glasoppervlak in ha.

\begin{tabular}{|c|c|c|c|c|c|c|}
\hline \multirow{2}{*}{ Year } & \multicolumn{2}{|c|}{ Vegetables } & \multirow{2}{*}{ Fruit } & \multicolumn{2}{|c|}{ Flowers } & \multirow{2}{*}{ Total } \\
\hline & Glasshouses & Frames & & Glasshouses & Frames & \\
\hline $\begin{array}{l}1906 \\
1912 \\
1940 \\
1950 \\
1960 \\
1965\end{array}$ & $\begin{array}{r}10 \overline{7} \\
1188 \\
1323 \\
3382 \\
4742\end{array}$ & $\begin{array}{l}178 \\
477 \\
924 \\
900 \\
635 \\
372\end{array}$ & $\begin{array}{r}28 \\
83 \\
856 \\
780 \\
468 \\
313\end{array}$ & $\begin{array}{r}19 \\
34 \\
224 \\
242 \\
449 \\
839\end{array}$ & $\begin{array}{l}21 \\
18 \\
61 \\
39 \\
50 \\
62\end{array}$ & $\begin{array}{r}246 \\
719 \\
3253 \\
3284 \\
4984 \\
6328\end{array}$ \\
\hline \multirow{2}{*}{ Jaar } & Kassen & Platglas & \multirow{2}{*}{ Fruit } & Kassen & Platglas & \multirow{2}{*}{ Totaal } \\
\hline & \multicolumn{2}{|c|}{ Groenten } & & \multicolumn{2}{|c|}{ Bloemen } & \\
\hline
\end{tabular}

1 from: Produktschap voor Groenten en Fruit

It is striking that between 1950 and 1960 the growth of vegetables under glass increased more than that of flowers, while after 1960 the emphasis is more on flowers. The growth of fruit under glass has decreased considerably. Another striking feature is the switching over from frames to glasshouses.

The heating of glasshouses has also increased. Of the vegetable and flower area about 65 procent can now be heated.

In 1965 the value of the total horticultural production under glass was about 700 million dutch guilders, the main products being tomato, lettuce, cucumber, freesia, chrysanthemum, carnation and rose.

TABLe 2. Production in $1963^{1}$.

Produktie in 1963.

\begin{tabular}{|c|c|c|c|c|}
\hline & $\times 1000$ & 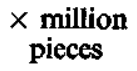 & $\begin{array}{l}\times \text { million } \\
\text { bunches }\end{array}$ & $\begin{array}{l}\times \text { million } \\
\text { guilders }\end{array}$ \\
\hline \multirow[t]{2}{*}{$\begin{array}{l}\text { Tomato / Tomaat } \\
\text { Lettuce / Sla } \\
\text { Cucumber / Komkommer } \\
\text { Freesia / Freesia } \\
\text { Chrysanthemum / Chrysant } \\
\text { Carnation / Anjer } \\
\text { Rose / Roos }\end{array}$} & $\begin{array}{c}225 \\
90 \\
154,5\end{array}$ & $\begin{array}{r}19,0 \\
179,1 \\
164,1\end{array}$ & $\begin{array}{r}18,1 \\
4,2\end{array}$ & $\begin{array}{l}229 \\
110,5 \\
82 \\
13,8 \\
13,5 \\
28 \\
33,1\end{array}$ \\
\hline & $\times 1000$ & $\times \underset{\text { stuks }}{\times \text { miljoen }}$ & $\times \underset{\text { bos }}{\text { miljoen }}$ & $\begin{array}{c}\times \text { miljoen } \\
\text { gulden }\end{array}$ \\
\hline
\end{tabular}

1 from: Tuinbouwgids 1964 
It is beyond the scope of this paper to give detailed production figures. I cannot refrain, however, from giving you some idea of them. Table 2 gives the production figures in 1963 of a few important products.

\section{CHANGES IN GROWING TECHNIQUES AND THE PHYTOPATHOLOGICAL CONSEQUENCES}

I should first like to summarize the changes that have taken place in growing techniques (Table 3) and then discuss the various points successively, with examples. These changes indicate the dynamic character of development in horticulture and the need for phytopathological research to be dynamic, too. It is of little use merely to give a survey of diseases in the past and in the present.

TABlE 3. Changes of growing techniques.

Veranderingen ten gevolge van verbeterde technieken.

Intensification: Intensivering:

Specialization: Specialisatie
Outdoor growing to growing under glass / Van teelt in de volle grond naar teelt onder glas

Unheated glass to heated glass / Van onverwarmde naar verwarmde teelt onder glas

Change in glasshouse structures / Verandering in de structuur van de kassen

Automation: Environmental control / Beheersing van de omgeving

Automatisering:

Mechanisation: Mechanisering:

\author{
Change in growing methods / Verandering van teeltmethodes \\ Earlier growing / Vroege teelt \\ One or two main crops / Een of twee hoofdteelten \\ Year-round production / Produktie gedurende het gehele jaar \\ Large units of glasshouses / Grote eenheden kassen \\ Labour saving / Besparing van arbeid \\ Resistant varieties / Resistente variëteiten \\ Supply holdings / Toeleveringsbedrijven
}

Disease control / Ziektenbestrijding

\section{The change from unprotected to protected cultivation}

A change from outdoor growing to growing under glass greatly affects the climatic conditions and hence the incidence of pests and diseases. This also applies to the change from the simplest method of coverage with glass, the so-called frames, to glasshouses, heated glasshouses or modern glasshouse structures. This is shown in outline in Fig. 1. Apart from changes in glasshouse structures, changes took place from solid fuel as a heating source to oil, or even natural gas, and many operations, such as temperature control, ventilation, watering can now be done automatically.

A change to protected cultivation has also been observed in Southern countries (e.g. in Israel and the Canary Islands) where some crops are now protected against direct weather influences by plastic or nylon.

Environmental changes, mainly in temperature and humidity, both above and below ground, are often decisive for the incidence of pests and parasitic and non-parasitic disease (CROSSAN \& LloYD, 1965). A disadvantage of unheated glass compared with heated glass is that temperature and humidity can be controlled only to a very limited extent. 


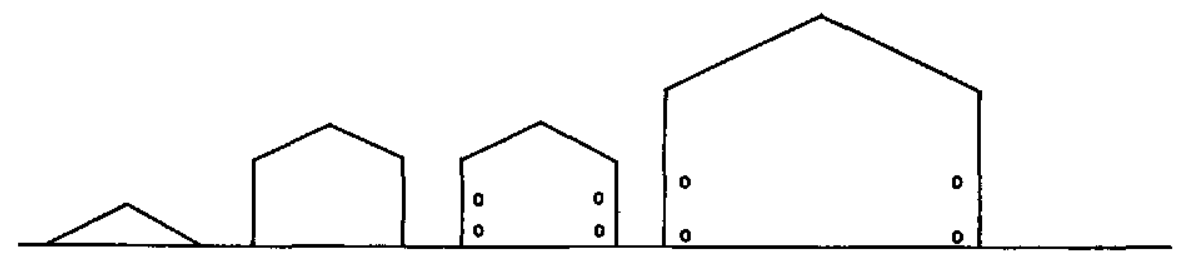

$\begin{aligned} \text { Frames/platglas glasshouse/kas heated/verwarmd } & \rightarrow \\ \text { solid fuel/vaste brandstof } & \rightarrow \text { oil (gas)/olie (gas) } \\ & \rightarrow \text { automation/automatisering }\end{aligned}$

Fig. 1. Glasshouse development.

Ontwikkeling van de kas.

The phytopathological consequences of coverage with glass may be illustrated by a few examples.

In temperate climates, the polyphagous root-knot nematodes (Meloidogyne $s p p$.) are quite generally found outdoors, but the extent of root infection is usually small because they develop slowly at low temperatures. The consequence of covering crops with glass is a rise in soil temperature and hence greater development possibilities for the nematodes and a greater risk of crop infection. This was first observed in tomatoes and cucumbers, but these nematodes also infect carnations and freesias. Furthermore since the cultivation of autumn lettuce has greatly increased, and that in a period when the soil temperature is still rather high, infection has also been observed in this crop.

As with the root-knot nematodes, the white fly (Trialeurodes vaporariorum) behaves polyphagously and is frequently found in the open. Under these conditions, however, it develops only to a limited extent, whereas under glass, and in particularly in hothouses, the rate of development of the insect increases greatly as also does its chance of survival, since nowadays crops are often produced under glass all the year round. It is thus necessary to maintain a greater watchfulness in respect to these parasites.

In the Canary Islands, where tomato production is of great importance, outdoor-grown crops suffer much from the rather strong winds from the African Continent. These winds may damage the fruits. This can partly be avoided by growing crops under nylon or plastic, but the resulting changes in the environment give rise to other disease problems, among which are grey mould (Botrytis cinerea) and leaf mould (Cladosporium fulvum). In Israel, where, in winter, tomatoes are also grown under plastic, the leaves and fruits of the plant may suffer from Phytophthora parasitica.

In crops covered with glass, the absence of the natural leaching of the soil with water led originally to a few difficulties of a non-pathogenic nature, such as growth stagnation and tipburn disease of lettuce and blossom end rot of tomatoes. In both crops these troubles were due to too high a salt concentration in the soil. Since, in growing under glass, the soil is leached artificially, the risk of these failures has greatly decreased. If, on the other hand, the soil has been overleached and the level of fertilization is insufficient, the fruits of the tomato may suffer from blotchy ripening.

Cladosporium fulvum, the fungus which causes leaf mould in tomatoes, is not 
found on outdoor-grown crops because the desired combination of high temperature and high air humidity is absent there. The disease is very common under glass, however, particularly in cold greenhouses, where humidity control is difficult. Since Japan has grown tomatoes in plastic houses, leaf mould could be found there too.

\section{Change in glasshouse structures}

In the fifties a rapid change occurred from growing under frames to growing in glasshouses, especially for cucumbers, but also for other crops such as lettuce and melons. From that time onwards there was a rapid development in glasshouse building, the tendency being towards larger units, with lower costs of investment per unit area, but at the same time improved environmental control. This enlarged the possibilities for crop rotation, crop specialization and disease control.

When cucumbers were cultivated under frames on a large scale, scab, caused by Cladosporium cucumerinum, frequently occurred. Though the development of resistant varieties solved this problem, the disease certainly would have disappeared with the shift from frames to glasshouses. The air humidity in glasshouses, particularly in heated houses, is lower, so that the fungus cannot develop.

Though the disappearance of this disease has been a point in favour of the change, the incidence of another disorder in cucumber - be it a non-pathogenic one - became a drawback. In glasshouses many bitter fruits began to be found. Occasionally bitter fruits had been found under frames, especially at the end of the growing season or after an infection with Fusarium oxysporum. The cause of this chemical disorder has mainly to do with the balance between water supply and evaporation, which is disturbed sooner under glasshouse conditions. If, after a dark period, the transpiration was high, bitter fruits could always be expected. Though some research has been done on the effect of different growing conditions on the occurrence of bitter fruits, the problem has been solved in practice by the introduction of bitterfree varieties.

Recently we have heard complaints about bitter gherkins, which are now grown in glasshouses on a large scale. In an outdoor crop the disease does not occur.

\section{Changes in growing methods}

Changes in growing methods often lead to changes in phytopathological measures; on the other hand, if effective control measures can be introduced, possibilities for cultivation under glass are extended.

Since the great development of glasshouse culture, crop specialization and intensification have assumed large proportions. Nurseries have specialized in a limited number of crops for which glasshouses are used almost without interruption.

The main vegetable crops, namely tomatoes, lettuce and cucumbers, which were formerly grown during about seven months of the year, have undergone such changes in methods that they are now grown throughout the year. This applies also to flower crops, such as chrysanthemums and freesias (Figs. 2 and 3 ), while, in the perennial crops, such as carnations and roses, there is a tendency towards production during the greatest possible period of the year. This devel- 


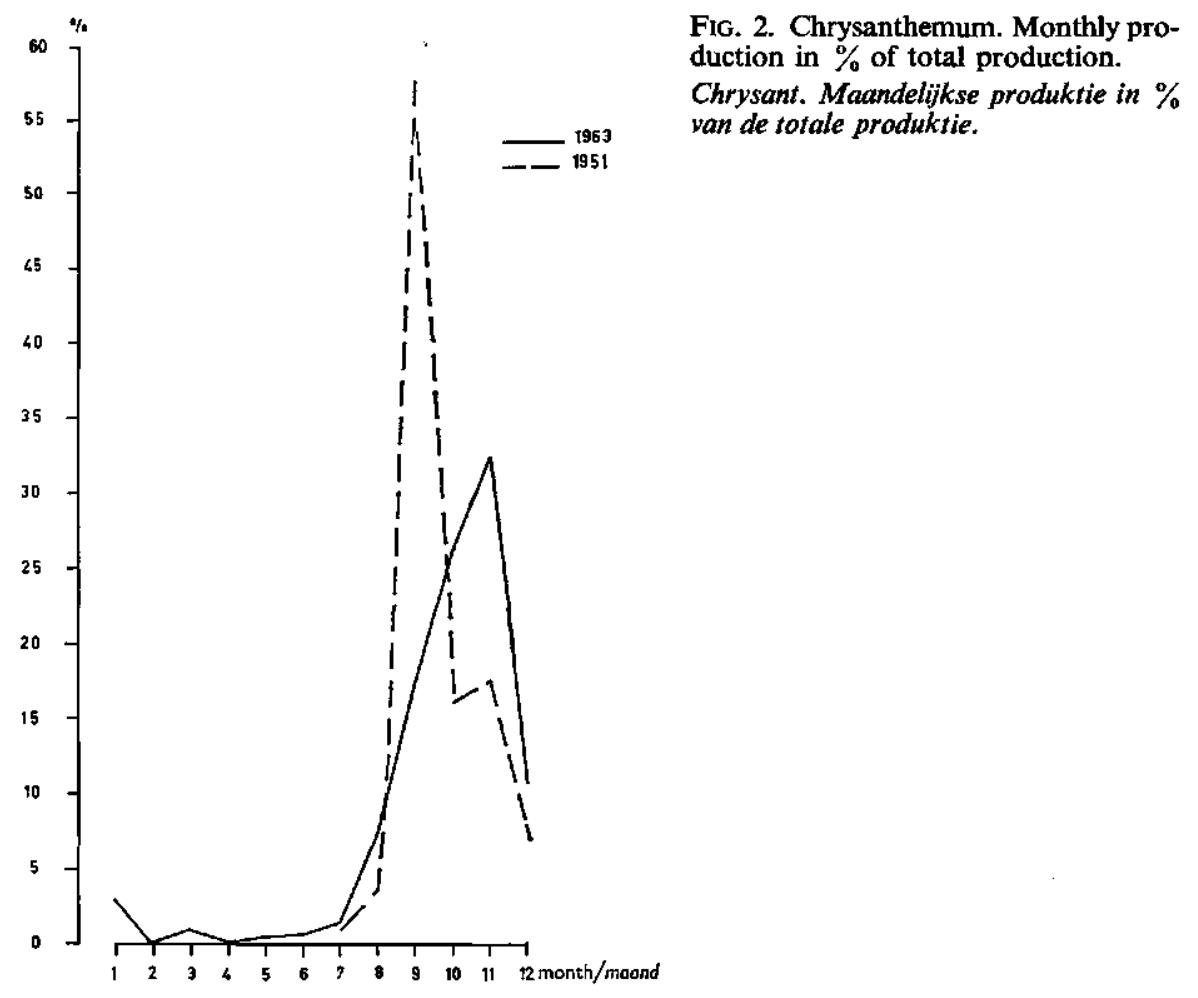

opment requires much attention to disease control, especially the control of soil diseases.

There have' been no spectacular developments in fruit-growing under glass. The area under fruit has even been reduced because the two other categories were economically more profitable.

The following examples are given to illustrate the above mentioned developments.

The planting dates of tomatoes grown in unheated houses as well as those in heated houses have gradually been advanced towards March and December/ January respectively. Especially in cold-house crops the incidence of stem rot caused by Didymella lycopersici has increased, due to low soil temperatures, which favour infection of the stem base via the roots. Infected plant debris in the soil is the main source of infection; it has been found that infested soil may remain infective for at least 18 months. The disease also occurred in heated crops, when planted at too low soil temperatures. Temperatures below $15^{\circ} \mathrm{C}$ are favourable to stem base infection (VERHOEFF, 1963). A stem rot infection might be the source of spread of the disease above ground. A sudden explosion of the disease took place in England after the war. It was worst in the outdoor crop, grown as a war-time measure, and was undoubtedly due to a build-up of inoculum, coupled with too low temperatures for good growth of tomatoes. Trouble was also experienced in many glasshouses, probably due to inadequate heating at that time. 


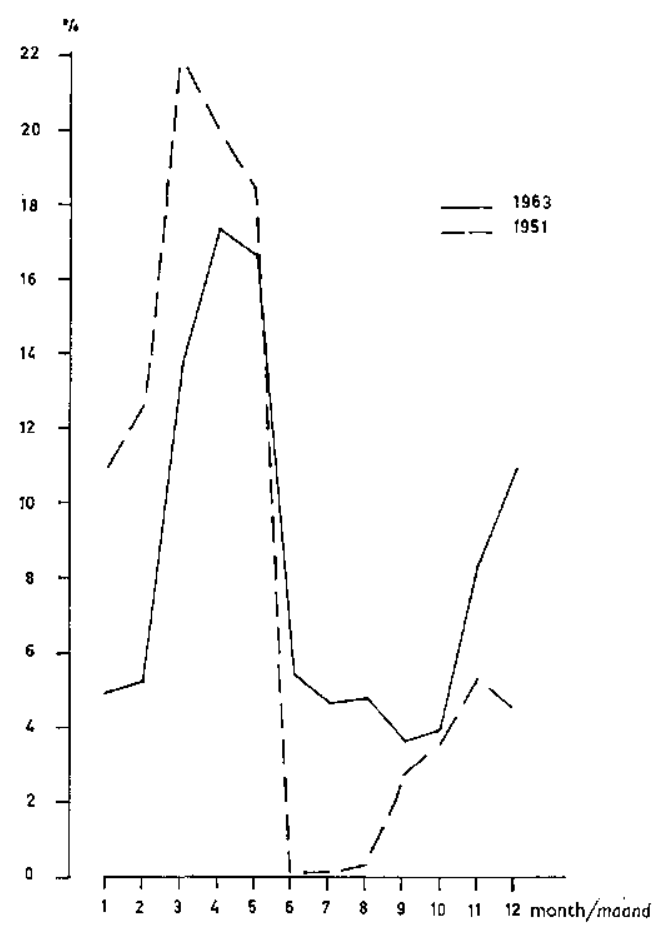

FIG. 3. Freesia. Monthly production in $\%$ of total production.

Fresia. Maandelijkse produktie in \% van de totale produktie.

As a result of the earlier planting date for tomatoes in heated houses the growing of lettuce in the autumn may be finished by October or November, thus saving some time for soil preparation for the following crop. With the expansion of lettuce growing at that time of the year, attacks of downy mildew (Bremia lactucae) increased rather rapidly (VERHOEFF, 1960). The conditions for the development of the fungus were favourable, due to the method of forcing the crop and fluctuations of temperature and humidity. Besides, decreasing daylength and light intensity were disadvantages to the growing crop. The disease causes a loss in yield, because the plants grow out irregularly and because the head does not develop well. Changes in growing conditions (especially control of temperature and humidity) and chemical control have contributed towards a decrease in the incidence of the disease.

Since 1960, when additional carbon dioxide as a growth factor began to be introduced into houses with autumn lettuce crops, it became possible to shorten the growing period. It was then easier to accomplish the aim of growing two lettuce crops after each other in the same house. This method has been responsible for an increase in the amount of Rhizoctonia disease, since inoculum could be build up more easily.

After the change to glasshouses in cucumber growing, powdery mildew, caused by Sphaerotheca fuliginea, became a common disease. Formerly, cucumbers could only be grown during part of the year and the fungus had consequently hardly any chance to survive. Nowadays cucumbers are grown throughout the year so that the fungus can survive and develop. Besides, the 
fungus develops better in glasshouses than under frames, because of the drier atmosphere.

A modification in the crop pattern may eliminate a disease. Several years ago many growers near Rotterdam forced chicory. This crop could be attacked by Sclerotinia sclerotiorum, and was responsible for the Sclerotinia disease of the following crop, tomatoes. Since growers have stopped the growing of chicory, this fungus disease is no longer a problem in tomatoes.

On the other hand, another crop sequence may introduce a disease to a new crop. For, after the introduction of flowers at a vegetable nursery, it appeared that carnations and freesias were also susceptible to nematodes. This means that if these flower crops are grown after cucumbers or tomatoes, which are susceptible to nematodes, the soil has to be disinfected.

Labour saving methods may sometimes be the cause of an increase in disease. Leaf picking is a normal cultural method in tomato growing. Of late, some growers have left the picked leaves under the crop between the paths, thus saving labour. If conditions are favourable, the dead leaves can become a source of Botrytis infection.

Because of the demand for roses during winter, there is a tendency to keep the plants growing and prevent the onset of a resting period. The wide-spread 'Baccara' variety does not lend itself very well for this method. The result is that in summer the wood ripens insufficiently and stem canker caused by Leptosphaeria coniothyrium may develop. Another consequence of the method is that the control of red spider mite must be continued.

A lot of research has been done to spread the production of freesias. Since we have got a better insight into the temperature treatment of freesia bulbs, flowers may be obtained throughout the year. To flower in winter, the freesias must be planted in the open in summer, though the risk of virus infection will then be great.

A clear example of a disease being a direct result of cultural handling is the following. Especially for the tomato crop in heated houses, the electric truss vibrator has been used on a large scale to provide a better setting of the first trusses. I never saw a better inoculation method for tomato mosaic virus, if but one plant in the house is infected. Apart from the spread of virus, however, this method is on the way out because the labour requirement is very intensive.

As regards grapes under glass an example of several years ago can be mentioned. It was then common to grow a catch crop of cauliflower before the grapes began to develop. The result was a later harvest of the grapes due to lower temperatures and poorer quality during storage. The position has improved since the growing of a catch crop has been abandoned.

\section{Development of resistant varieties}

The breeding of resistant varieties is one of the methods to control diseases. It depends entirely on the type of crop, on the disease and on the costs of the breeding work if this method should be preferred to the other two, control of environment or chemical control.

Great differences exist between agriculture, fruit growing and vegetable and flower growing under glass in this respect. In agriculture for example, environmental control is almost impossible, whereas chemical control is only possible to a certain extent. Thus in agriculture it is more or less essential to look for resistant varieties. 
In fruit growing, time is the bottle-neck for breeding resistant varieties. One of the objections is that the popularity of varieties may have changed before the breeding programme is finished.

Several vegetables and to a certain extent also some flowers lend themselves rather well for a disease-resistance breeding program. Especially cucumber, with its short life cycle, has already been used with success in such a programme. On the other hand it depends upon the damage caused by the disease and the relative simplicity of controlling it by changing the environment or with chemicals, wether a breeding programme should be chosen. Tomato mosaic, for example, or a vascular disease in carnations caused by Phialophora cinerescens both of which are difficult to control, could best be combated by breeding resistant varieties. Though it is difficult to determine the costs of breeding, it is assumed that breeding will be profitable because those diseases cause so much damage.

In spite of the relative better possibilities for breeding disease-resistant varieties in glasshouse culture, the successes so far have not been numerous. One of the reasons is that many diseases can be controlled easily, effectively and relatively cheaply by chemical means. Moreover, a new resistant variety is accepted by the grower only if the level of production (quantitative and qualitative) is at least equal to that of the original susceptible variety.

I have already given a few examples of resistance breeding. It would be useful to give a few more results. Leaf mould in spinach (Peronospora spinaciae) is a disease which can be controlled only with difficulty because it spreads so rapidly; moreover, the product is soon ready for harvesting while, in a certain stage of cultivation, chemical control methods are not allowed. The development of resistant varieties has greatly reduced the risks of growing this crop.

Tomato varieties have been bred which are resistant to leaf mould (Cladosporium fulvum), which is of special importance in tomato production in unheated houses and in autumn cultivation (TERMOHLEN, 1960). When these varieties are grown, the absence of chemical control results in an increase of Phytophthora infection, against which these varieties are not resistant. Though fewer sprayings will suffice, control cannot be omitted. This does emphasize the fact that a combined resistance against more than one disease might be desirable.

In carnation growing there has been a general switch over to the American 'Sim' varieties. Although these varieties are not a product of resistance breeding, they are rather resistant to Fusarium.

\section{The development of supply holdings}

To grow planting material, much potting soil is used in horticulture under glass. For the approximately 100 million tomato plants which are annually needed, not to mention the numerous cucumber and lettuce plants, it is clear that very large quantities are concerned. Special farms have gradually taken up the supply of potting soil.

Furthermore, special nurseries for plant propagation have been set up which supply this planting material against order. Many growers lack the special glasshouse equipment needed to produce the young plants themselves, or do not want to have the trouble.

The greatest possible care in hygiene is expected from these special farms because the risk of introduction of parasites on the holdings along this way is not 
imaginary. Arabis mosaic in cucumber, for example, transmitted by nematodes, can be spread by means of the potting soil (VAN DoRST \& VAN HooF, 1965). One of the components of the potting soil may contain the nematodes, which became infected via one of the host plants of the virus.

Cucumbers are grafted on the rootstock Cucurbita ficifolia because of its resistance to wilt disease caused by the fungus Fusarium oxysporum. This grafting is done on a large scale by supply holdings. The rootstock is susceptible to Fusarium javanicum var. ensiforme, however. If rootstock seed is taken from diseased fruit, the seeds may have been infected and spread the disease via the supply holdings; the cucumber is also susceptible to this Fusarium.

Because of the great expansion of chrysanthemum growing, especially the year-round cultivation, much cutting material is supplied by special farms. The Ascochyta disease (Mycosphaerella ligulicula), which does not infect outdoor chrysanthemums in the Netherlands, has been introduced into this country by cuttings imported from abroad. Some widely grown cultivars are highly susceptible; one should therefore inspect the imported cuttings very carefully. Of late, the white rust (Puccinia horiana) has been imported in the same way.

The year round cultivation of chrysanthemums also offered possibilities for a year round cycle of the chrysanthemum fly Phytomyza atricormus.

\section{The development of environmental control}

The enormous expansion of glasshouse building I mentioned before, was accompanied by marked improvements in equipment controlling the environment, such as heating systems, automatic control of temperature, spraylines for water and fertilizer supply, and ventilation. All these contributed towards the development of glasshouse structures in which the climate could be better regulated and more favourable for the crops. Through research and close contact between research and practical experience we have also obtained a better insight into the growing conditions required by most glasshouse crops, and over and above this, we have had the introduction of better varieties.

of course growers readily accepted the improved growing possibilities, overlooking the fact that these might have phytopathological consequences. Fortunately, better climatic control often confers an advantage in disease control. If, for example, a grower puts enough heat into his glasshouse before planting tomatoes, there is little or no fear for Didymella infection. Good control of temperature and humidity may also to a large extent prevent infection of the tomato with Cladosporium fulvum and give less Botrytis on fruit, stem and leaves.

Roses grown in badly ventilated glasshouses run the risk of being infected by downy mildew caused by Peronospora sparsa. The disease need not occur in modern glasshouses with better ventilation control. The same applies for rust in carnations (Uromyces dianthi).

\section{The development of chemical disease control}

The development of disease control has kept pace with the intensification and specialization of horticulture under glass. There is an interaction between the two. Though a change in growing methods may involve phytopathological consequences, phytopathological control itself may increase the growing possibilities. This is clearly demonstrated by the fact that the more intensive crop rotations and the year-round production called attention to the importance of soil- 
borne disease. The development of soil disinfection, either by steaming or by the use of chemicals, has lengthened the period of cultivation of several crops and opened the possibility for a more rapid crop rotation. The important factors here are the length of the effective period of the chemicals and the shortness of the waiting period after the treatment. Most of this work is done by contractors and mechanisation of the work has increased very rapidly.

A common crop rotation in vegetables is lettuce, followed by tomatoes or cucumbers. Especially for the latter two it is necessary to disinfect the soil regularly. If soil disinfection is done before the lettuce crop, the plants show too luxurious a growth on several soil types. One should then either find cultural methods to prevent this occurring, or disinfect the soil after the lettuce crop, accepting the fact that the time between the lettuce crop and the following crop is rather short.

Chemical disease control above ground has also been intensified and is likewise done by contractors on a large scale. A rapid change from inorganic to organic chemicals offered possibilities for more specific and precise control measures. An example is the development, since 1945, of good pesticides against red spider mite in cucumber; this has considerable lengthened the growing period of this crop. The same holds for thrips in cucumber and grapes; this pest has been eradicated completely.

Nowadays it is impossible to think of lettuce growing in winter without the application of good chemicals to control Botrytis, Sclerotinia and Rhizoctonia.

It is also unthinkable that control of rust or red spider in carnations, or powdery mildew in roses should be omitted. This would at once impair the quality of the produce. The quality of the glasshouse product will more and more have to be emphazised in future. From the point of view of the grower, crop depression due to disease control cannot be allowed. From the point of view of the consumer, quality depression cannot be allowed. This puts great responsibilities on those working for chemical control. If chemicals are used, attention must also be paid to toxicity, both for plant and for human beings, and to residue formation on the crop.

\section{CONCLUSION}

Intensification, specialization, mechanization, automation and cultural care require much of the grower.

Cultural care includes chemical disease control, disease control by breeding resistant varieties, and cultural care in a more restricted sense, such as control of the environment (GILBERT \& TANAKA, 1965). Only if intensification and specialization work together in close harmony they will give the highest yields of good quality produce.

The tendency in horticulture is towards the extension of the growing possibilities, the enlargement of production per unit area, the improvement of quality and reduction of costs.

Control of both environment and disease naturally raises costs. But the development of ever more effective methods, better application methods and the help of special contractors for disease control have contributed to making this rise as small as possible. Though with the development of control against a certain disease, the costs will have to be considered (LE CLERG, 1964), the slight increase in general costs will often be offset by improvements in production and/or quality. 
One should always be aware of the constant interaction between changes in growing methods on the one hand and phytopathological aspects on the other.

\section{SUMMARY}

The increase of the glasshouse industry and the concentration in North West Europe are discussed and some figures on glasshouse area and crop production in the Netherlands are given.

The dynamic character of both horticultural development and disease control are described as intensification, specialization, automatization and mechanisation. The phytopathological consequences of changing growing techniques in horticulture under glass are illustrated by several examples.

Special attention is given to the change from unprotected to protected cultivation and the type of glasshouse structures being used, to changes in growing methods, to the development of disease resistant varieties and to the development of chemical disease control.

\section{SAMENVATTING}

De intensivering van de tuinbouw onder glas heeft steeds beoogd de produktie te spreiden, de produktie per eenheid van oppervlakte te vergroten, de kwaliteit van het geoogste produkt te verhogen en de kostprijs te verlagen. Deze ontwikkeling bracht met zich mee dat aan de bestrijding van ziekten en plagen veel aandacht moest worden besteed. Gebleken is dat de kosten van bestrijding relatief laag zijn.

De cultuur onder glas is voornamelijk geconcentreerd in N.W.-Europa, vooral in Nederland, waaraan het gematigde klimaat debet is. De uitbreiding van het glasareaal werd vooral gestimuleerd door de sterk toegenomen vraag naar kwaliteitsprodukten die het gehele jaar vers gekocht kunnen worden. Het totale areaal in Nederland was in 1965 ruim 6300 ha, waarvan ongeveer $65 \%$ kan worden verwarmd (tabel 1, fig. 1). De sterkste uitbreiding vond plaats na de tweede wereldoorlog. De belangrijkste produkten zijn tomaat, sla, komkommer, freesia, chrysant, anjer en roos (tabel 2, fig. 2 en 3).

Het dynamische karakter van de tuinbouw onder glas wordt gekarakteriseerd door intensivering, specialisering, automatisering en mechanisering (tabel 3).

De omschakeling van de teelt in de vollegrond naar de teelt onder glas beïnvloedt de klimaatsomstandigheden dusdanig, dat bepaalde parasieten, bijv. nematoden (Meloidogyne spp.) en witte vlieg (Trialeurodes vaporariorum), betere kansen krijgen voor hun ontwikkeling, daarbij nog geholpen door het feit dat de gewassen onder glas het gehele jaar door geteeld kunnen worden. Bedekking van de grond met glas verhindert het op natuurlijke wijze uitspoelen van de grond met water. De verhoging van de zoutconcentratie in het bodemvocht kan aanleiding geven tot afwijkingen in de gewassen van niet-pathogene aard. Door de grond kunstmatig met water door te spoelen kunnen dergelijke afwijkingen worden voorkomen.

De klimaatsomstandigheden veranderen ook als platglas veranderd wordt in staand glas of als koud glas wordt verwarmd. Bij komkommers kwam vruchtvuur, veroorzaakt door Cladosporium cucumerinum, algemeen voor. Onder staand glas zijn door een lagere luchtvochtigheid de ontwikkelingskansen voor deze schimmel vrijwel nihil; bovendien werden rassen gekweekt die tegen deze 
ziekte resistent zijn. Bittere vruchten bij komkommers kwamen onder platglas bijna niet voor; onder staand glas werd deze fysiogene afwijking een probleem, dat is opgelost door het kweken van resistente rassen.

De tuinbouwbedrijven hebben zich gespecialiseerd op een beperkt aantal gewassen, waarvoor de glasopstanden bijna zonder onderbreking het gehele jaar worden gebruikt. Dit betekende een intensivering van de bestrijding van ziekten; door het intensieve grondgebruik moest vooral veel aandacht worden geschonken aan bodemziekten.

De neiging tomaten steeds vroeger uit te planten in koude kassen veroorzaakte een toename van de aantasting door Didymella lycopersici (kanker), ten gevolge van de lagere bodemtemperatuur. De teelt van sla in de herfst is sterk toegenomen doordat tomaten in verwarmde kassen steeds vroeger worden uitgeplant en sla - tomaat een bekende teeltopvolging is. Dit had bij sla het optreden van het wit (Bremia lactucae) tot gevolg. Doordat komkommers spoedig het gehele jaar onder glas werden geteeld, werden betere kansen geboden aan de schimmel Sphaerotheca fuliginea, die 't wit veroorzaakt.

Het kweken van resistente rassen neemt een belangrijke plaats in als onderdeel van de ziektenbestrijding. Meer dan bij bloemen en fruit heeft deze wijze van ziektenbestrijding resultaat bij groenten, vooral door de kortere levenscyclus van de groentegewassen. Een belangrijke factor bij het kweken van resistente rassen is de eis die - buiten de eigenschap van resistentie - kwantitatief en kwalitatief aan het produkt gesteld wordt.

In de tuinbouw zijn op velerlei gebieden toeleveringsbedrijven ontstaan. Hierbij nemen de bedrijven die potgrond of plantmateriaal leveren een belangrijke plaats in. Dit houdt het gevaar in dat met de potgrond en met het plantmateriaal bepaalde ziekten op het tuinbouwbedrijf worden geïntroduceerd. Zo wordt Arabis-mozaïek bij komkommer overgebracht door aaltjes die met de potgrond zijn meegekomen. De Ascochyta-ziekte (Mycosphaerella ligulicula) bij chrysant is met het stekmateriaal van elders geïmporteerd.

De ontwikkeling die bestaat ten aanzien van de automatisering van het kasklimaat (verwarming, ventilatie, voorziening met water en voedingsstoffen) heeft er veel toe bijgedragen, dat een aantal ziekten beter onder controle kan worden gehouden.

Er bestaat een sterke interactie tussen de ontwikkeling van de teelten onder glas en de ontwikkeling van de ziektenbestrijding. Een ontsmetting van de grond tegen bodemparasieten, noodzakelijk geworden door een intensivering van het teeltpatroon, opende op haar beurt de mogelijkheid tot een verdere intensivering. De organische chemische bestrijdingsmiddelen, die vrij snel de anorganische hebben vervangen, hebben ten opzichte van bepaalde parasieten een betere specifieke werking. Dit gaf verruiming van de teeltmogelijkheden, doordat zelfs sommige ziekten geheel verdwenen.

\section{REFERENCES}

BARNES, E. H., - 1954. Changing plant disease losses in a changing agriculture. Phytopathology 54: 1314-1319.

Chester, K. S., - 1950. Plant disease losses: their appraisal and interpretation. Suppl. Pl. Dis. Reptr 190: 190-362.

Clerg, E. L. LE, - 1964. Crop losses due to plant diseases in the United States. Phytopathology $54: 1309-1313$.

Crossan, D. F. \& P. J. Lloyd, - 1965. The influence of overhead irrigation on the incidence and control of certain tomato diseases. Pl. Dis. Reptr 40: 314-317. 
DORST, H. J. M. VAN \& H. A. VAN Hoof, - 1965. Arabis mozaiek virus bij komkommer in Nederland. Neth. J. Pl. Path. 71: 176-179.

GLBERT, J. C. \& J. S. TANAKA, - 1965. Horticultural refinement of multiple disease resistant tomatoes in Hawaii. Hawaii Fm Sci. 14: 4-6.

MINISTERIR YAN LANDBOUW EN VISSERIJ, - 1964. Tuinbouwgids, Staatsdrukkerij en Uitgeverijbedrijf, Den Haag.

TERMOHLEN, G. P., - De fysiologische specialisatie van Cladosporium fulvum en het kweken van tegen de bladvlekkenziekte resistente tomaterassen. Tijdschr. PIZiekt. 66: 314-327.

ThraN, P. \& S. BRoEkHUIZEN, - 1965. Agro-ecological atlas of cereal growing in Europe, vol. 1. Elsevier Publishing Company, Amsterdam.

VerHOEFF, K., - 1960. On the parasitism of Bremia lactucae Regel on lettuce. Tijdschr. PlZiekt. 66: 133-203.

VERHORFF, K., - 1963. Voetrot en ,kanker" bij tomaat, veroorzaakt door Didymella lycopersici. Neth. J. Pl. Path. 69: 298-313. 